\title{
McKenzie Therapists Adhere More to Evidence-Based Guidelines and Have a More Biopsychosocial Perspective on the Management of Patients with Low Back Pain than General Physical Therapists in Japan
}

\author{
Hiroshi Takasaki ${ }^{*}$, Takeshi Saiki², Yoshihiro Iwasada ${ }^{3}$ \\ ${ }^{1}$ Division of Physical Therapy, Saitama Prefectural University, Koshigaya, Japan \\ ${ }^{2}$ Physical Therapy Department, Medical and Health Faculty, Yamato University, Suita, Japan \\ ${ }^{3}$ The McKenzie Institute International, Japan Branch, Fujimi, Japan \\ Email: physical.therapy.takasaki@gmail.com
}

Received 12 August 2014; revised 16 September 2014; accepted 12 October 2014

Academic Editor: Takaya Narita, Department of Physical Therapy, Health Science University, Japan

Copyright (C) 2014 by authors and Scientific Research Publishing Inc.

This work is licensed under the Creative Commons Attribution International License (CC BY). http://creativecommons.org/licenses/by/4.0/

(c) (i) Open Access

\section{Abstract}

Design: Cross-sectional. Objective: Aim 1 was to preliminarily explore the contributions of the following factors to adherence to LBP practice guidelines using regression modeling: 1) the credential qualification of Mechanical Diagnosis and Therapy (MDT); 2) balance of biomedical and behavioral (i.e. biopsychosocial) oriented approach for low back pain (LBP); 3) demographics; 4) academic degree and 5) the attitude towards updating information for evidence-based clinical practice. Aim 2 was to investigate whether therapists credentialed in MDT (Cred.MDT) were more behavioral oriented and less biomedical oriented than general physical therapists. Summary of Background Data: LBP practice guidelines are not adhered to by every physical therapist. MDT is a behavioral modification approach. Thus, it was hypothesized that the Cred.MDT therapist was more behavioral oriented and more adherent to LBP practice guidelines compared with general physical therapists. Methods: One-hundred-twenty Cred.MDT therapists and 2000 general physical therapists in Japan were contacted. For regression modeling, the dependent variable was adherent to guidelines using a questionnaire with a vignette. Independent variables included balance of biomedical and behavioral perspectives for LBP using the Pain Attitudes and Beliefs Scale for Physiotherapist (PABS-PT), demographics, academic degree and the attitude towards updating

\footnotetext{
${ }^{*}$ Corresponding author.
}

How to cite this paper: Takasaki, H., et al. (2014) McKenzie Therapists Adhere More to Evidence-Based Guidelines and Have a More Biopsychosocial Perspective on the Management of Patients with Low Back Pain than General Physical Therapists in Japan. Open Journal of Therapy and Rehabilitation, 2, 173-181. http://dx.doi.org/10.4236/ojtr.2014.24023 
information for evidence-based clinical practice. The ratio of the two mean scores of the biomedical and behavioral subscales in the PABS-PT was compared between the Cred.MDT therapist group and the general physical therapists group. Results: Data of 46 general physical therapists and 44 Cred.MDT therapists were available. The Cred.MDT therapist group was significantly $(P<0.05)$ more behavioral oriented and more adherent to LBP practice guidelines compared with the general physical therapist group. The regression indicated significance of the two predictors of adherence to guidelines, Cred.MDT $(\beta=0.58, P<0.001)$ and academic degree $(\beta=0.19, P=0.03)$. Conclusions: Cred.MDT therapists are more guideline-consistent and have a more biopsychosocial treatment orientation than general physical therapists in Japan.

\title{
Keywords
}

\author{
Clinical Behavior, Clinical Decision Making, Clinical Guidelines, Low Back Pain, Mechanical \\ Diagnosis and Therapy
}

\section{Introduction}

Low back pain (LBP) practice guidelines have been developed and disseminated to facilitate evidence-based clinical practice in primary care for LBP. Adherence to guidelines is useful to improve clinical outcomes with lower utilization of care and reduced cost [1]-[3]. However, LBP practice guidelines are not adhered to by every physical therapist [2]. Therefore, it is important to identify factors which predict adherence to guidelines by therapists in order to consider better educational strategies for physical therapists managing patients with LBP.

Current guidelines reflect the biopsychosocial nature of non-specific LBP and suggest the importance of considering using a behavioral-oriented approach to manage LBP [4]. Hendrick et al. [5] found that less biomedical oriented approach was associated with adherence to LBP practice guidelines. Therefore, we contend that the management of LBP from both biomedical and behavioral perspectives and other potential factors may be associated with adherence to guidelines [5] [6], for example, demographic factors, the highest education level attained, the attitude of therapists towards self-directed learning to facilitate evidence-based clinical practice (e.g. participation in workshops and conferences, and engaging in literature review).

Mechanical Diagnosis and Therapy (MDT) or the McKenzie approach is one of the common approaches for LBP [7]-[9]. One of the distinct features of MDT includes patient education to attain self-management strategies through self-monitoring of symptoms [10]. In doing so, MDT is considered to be a behavioral modification approach and we postulate that the attitude of therapists credentialed in MDT (Cred.MDT therapists) towards LBP is more behavioral oriented and less biomedical oriented and that Cred.MDT therapists are more adherent to LBP practice guidelines, compared with general physical therapists.

Ideally, all possible relevant variables should be included in a model which predicts adherence to LBP guidelines. However, a large sample would be required to undertake such an extensive study [11] [12]. In order to better understand the potential factors contributing towards adherence to LBP practice guidelines, it would be considered prudent to undertake a preliminary investigation for now.

The purpose of this study was twofold. The primary purpose was to undertake a preliminary exploration of the contributions of the following factors to adherence to LBP practice guidelines: 1) credential MDT qualification status; 2) the balance between biomedical and behavioral perspectives during LBP management; 3) demographic factors; 4) the highest education level attained and 5) the attitude towards self-directed learning to facilitate evidence-based clinical practice. The secondary purpose was to investigate whether Cred.MDT therapists were more behavioral oriented and less biomedical oriented than general physical therapists.

\section{Methods}

\subsection{Participants}

This study included two groups of therapists who treated patients with LBP. One group consisted of the 120 Japanese physical therapists who had obtained the credential MDT qualification (Cred.MDT) at January 2013 (Cred.MDT therapist group). The other group consisted of physical therapists without credential MDT qualifica- 
tion who participated in the 49th Congress of the Japanese Physical Therapy Association in 2014, in which 8000 therapists participated (general physical therapist group).

Survey with voluntary response sampling was used in this study for both groups and data was collected anonymously. For the Cred.MDT therapist group, the sets of questionnaires were distributed via e-mail to the registered Cred.MDT therapists. The response was possible on the web for one month. An email reminder was not undertaken. For the general physical therapist group, 2000 surveys were distributed randomly by hand to the eligible physical therapists as it was expected that approximately 2000 therapists are interested or specialized in musculoskeletal physical therapy, considering $17.8 \%$ of the proportion of presentations regarding musculoskeletal physical therapy registered to all 895 presentations registered in the congress (unpublished data). The response was possible with the hard copy during the congress or on the web for one month.

Exclusion criteria were a participant with missing data. Ethical approval for the study was obtained from the Research Ethics Committee of the Society of Physical Therapy Science in Japan. The response to the survey was handled as the consent for their participation in this study.

\subsection{Adherence to LBP Practice Guidelines}

Adherence to LBP practice guidelines was assessed using established three questions for a vignette of a patient with LBP [13] [14], which was a typical case of acute, nonspecific LBP without red flags indicating possible serious spinal pathology. The three questions were regarding activity, work and bed-rest. Each question has five different assertions and responses were dichotomized into "guideline-inconsistent" or "guideline-consistent" based on expert consensus for lenient interpretation as consistent with guideline recommendations [14]. For this study, the vignette and questions were translated into Japanese through recommended procedures for cross-cultural adaptation [15] with two forward-translations and two backward-translations (Appendix 1).

\subsection{Balance between Biomedical and Behavioral Perspectives for LBP Management}

This study used a translated version into Japanese of the Pain Attitudes and Beliefs Scale for Physiotherapist (PABS-PT) that was originally developed in 2003 by Ostelo et al. [16] and modified in 2005 by Houben et al. [17]. Similarly to adherence to LBP practice guidelines, the translation was undertaken through recommended procedures for cross-cultural adaptation (Appendix 2) [15]. The PABS-PT is an established measure of therapist's attitude toward LBP with 19 items and has two subscales of "biomedical" (10 items) and "behavioral" (9 items) [17]. Strong biomedical oriented approach is that therapists believe in a biomechanical model of disease, where disability and pain are a consequence of specific tissue pathology and treatments should be designed to treat the pathology. Strong behavioral oriented approach is that therapists believe in a biopsychosocial model of disease, where disability and pain do not have to be a consequence of tissue damage and can be influenced by psychological and social factors. The response is a six-point Likert scale ( $1=$ totally disagree, $6=$ totally agree $)$ and greater scores on each subscale indicate a stronger biomedical or behavioral treatment orientation, respectively. In order to consider the balance of biomedical and behavioral perspectives for LBP treatment in each participant, this study calculated mean score in each subscale and computed a ratio (biomedical/behavioral ratio). Therefore, the greater biomedical/behavioral ratio $(>1)$ indicated more weight on biomedical treatment orientation than biopsychosocial treatment orientation, and the smaller biomedical/behavioral ratio $(<1)$ indicated a more weight on biopsychosocial treatment orientation than biomedical treatment orientation.

\subsection{Other Co-Variables}

Demographic information was collected on participant's gender and age. The highest education level attained was categorized into a 3-ordinal scale $(1=$ less than Bachelor degree, $2=$ bachelor degree and $3=$ post-graduate degree). The attitude of therapists towards self-directed learning to facilitate evidence-based clinical practice was examined in 1) the number of external seminar, such as study meetings, lectures, workshops and conferences per year; 2) the number of academic papers in Japanese read per month; and 3) the number of academic papers in English read per month.

\subsection{Statistics}

Variables except adherence to LBP practice guidelines were substituted using the mode for missing data. The following three analyses were conducted. 
While developing a model to identify promising variables that contributed to adherence to LBP practice guidelines, the three dichotomized variables of adherence to guidelines were summed and used as one dependent variable (ranging from 1 to 4), where greater values indicated greater adherent to LBP practice guidelines. Categorical multiple regression models were built with all 8 variables (1: general physical therapist $\{1\}$ or Cred.MDT therapist $\{2\}$; 2: biomedical/behavioral ratio; 3 : men $\{1\}$ or women $\{2\}$; 4 : age; 5 : the highest education level attained $\{1-3\}$; 6 : the number of participation in external seminar per year; 7 : the number of academic papers in Japanese read per month; 8: the number of academic papers in English read per month).

In each of the three items of adherence to guidelines, the proportion of the guideline-inconsistent and guideline-consistent was compared between the general physical therapist group and Cred.MDT therapist group in order to further consider the difference in adherence to guidelines between the groups. Fisher's exact test was conducted.

The biomedical/behavioral ratio was compared between the general physical therapist group and Cred.MDT therapist group in order to examine the difference in the attitude towards LBP management. Two-tailed independent sample t-test was used as normal distribution of data was confirmed with the Kolmogorov-Smirnov test.

All statistical analyses were performed with SPSS version 21.0 (IBM Corporation, New York, USA). The level of significance was set at $\mathrm{P}<0.05$.

\section{Results}

Fifty-six Cred.MDT therapists and 53 general physical therapists participated in the study. However, eight Cred.MDT therapists and seven general physical therapists were excluded due to missing data of adherence to LBP practice guidelines. Therefore, response rate for available data was $36.6 \%$ and $2.3 \%$ in the Cred.MDT therapists group and the general physical therapist group, respectively.

Table 1 presents the variables in each group. The Cred.MDT therapist group was statistically $(\mathrm{P}<0.05)$ more guideline-consistent than the general physical therapist group across activity, work and bed-rest. Further, the Cred.MDT therapist group had a statistically $(\mathrm{P}<0.001)$ lower biomedical/behavioral ratio, where the upper limit of $95 \%$ CI was $<1$, than the general physical therapist group.

The results of the regression indicated that the two variables explained $62.7 \%$ of the variance of adherence to LBP practice guidelines $\left(\mathrm{R}^{2}=0.39\right.$, adjusted $\left.\mathrm{R}^{2}=0.33, \mathrm{~F}(9,80)=5.76, \mathrm{P}<0.001\right)$. It was found that the Cred.MDT therapist significantly predicted adherence to LBP practice guidelines $(\beta=0.58, \mathrm{P}<0.001)$, as did the highest education level attained $(\beta=0.19, \mathrm{P}=0.03)$.

\section{Discussion}

Of the variables examined, the presence of Cred.MDT was the primary contributor and the highest educational level was the secondary contributor to adherence to LBP practice guidelines. This study also revealed that the clinical practice of Cred.MDT therapists was more in line with LBP guidelines and that their practice was more biopsychosocial-orientated, as opposed to the general physical therapist group.

This study revealed that $74 \%$ of the general physical therapist group was guideline-consistent for activity, but only $57 \%$ and $20 \%$ of them were guideline-consistent for work and bed-rest, respectively. It is tempting to speculate that the general physical therapists group in our study were more motivated and inclined to practice evidence-based physical therapy than the majority of physical therapists in Japan considering the fact that we have sampled those who participated in the biggest national conference of physical therapy in Japan. Therefore, we would expect that the average adherence to LBP guidelines of the total population of physical therapy in Japan to be lower than the guideline-consistent values of $57 \%$ (work) and $20 \%$ (bed-rest) found in this study. Nevertheless, the three ratios of the general physical therapists who were consistent with guidelines seem to be lower than those of physical therapists in New Zealand (activity, 92.9\% guideline-consistent; work, 95.3\% guidelineconsistent; bed-rest, $100 \%$ guideline-consistent) [5] and, in particular, the response options of bed-rest in the current study (Appendix 1) are highly comparable to those in the previous study [5]. This indicates that dissemination of evidence-based clinical practice for LBP is limited in Japan. Based on our findings, we propose that follow-up actions using many strategies (such as workshops, symposiums, internet, flyers, newspapers and magazines) would be necessary to improve the quality of management for patients with LBP in Japan.

This study also revealed that neither demographics nor the magnitude of reading papers and attending outside seminars influenced adherence to LBP practice guidelines. However, it is considered that the magnitude of reading papers amongst Japanese therapists including MDT therapists would not be sufficient to keep abreast of 
Table 1. Descriptive analysis of variables in each group.

\begin{tabular}{|c|c|c|}
\hline Variables & $\begin{array}{l}\text { Cred.MDT therapist } \\
\mathrm{n}=44\end{array}$ & $\begin{array}{l}\text { General physical therapists } \\
\mathrm{n}=46\end{array}$ \\
\hline \multicolumn{3}{|l|}{ Adherence to low back pain practice guidelines } \\
\hline Total score (range 1 - 4) & $3.4(3.2-3.7)$ & $2.5(2.3-2.7)$ \\
\hline Guideline-consistent in activity ${ }^{*}$ & 42 [95] & 34 [74] \\
\hline Guideline-consistent in work $^{*}$ & 34 [77] & 26 [57] \\
\hline Guideline-consistent in bed rest $^{*}$ & $31[70]$ & $9[20]$ \\
\hline \multicolumn{3}{|l|}{$P A B S-P T$} \\
\hline Biomedical/behavioral ratio $^{\dagger}$ & $0.87(0.81-0.93)$ & $1.19(1.11-1.26)$ \\
\hline \multicolumn{3}{|l|}{ Demographics } \\
\hline Men & 32 [73] & 38 [86] \\
\hline Age (years) & $37.4(35.0$ - 39.8) & $34.5(32.5-36.6)$ \\
\hline \multicolumn{3}{|l|}{ The highest education level attained } \\
\hline Less than Bachelor degree & 27 [59] & $23[50]$ \\
\hline Bachelor degree & $13[28]$ & $13[28]$ \\
\hline Post-graduate degree & $4[9]$ & $10[22]$ \\
\hline \multicolumn{3}{|l|}{$\begin{array}{c}\text { Attitude of therapists towards self-directed learning to facilitate evidence-based } \\
\text { clinical practice }\end{array}$} \\
\hline The number of participation in external seminar per year & $7.5(5.0-9.9)$ & $5.8(3.9-7.6)$ \\
\hline The number of academic papers in Japanese read per month & $3.7(2.4-5.0)$ & $3.0(2.2-3.9)$ \\
\hline The number of academic papers in English read per month & $1.6(0.2-2.9)$ & $0.9(0.2-1.6)$ \\
\hline
\end{tabular}

Abbreviations: Cred.MDT, credentialed in Mechanical Diagnosis and Therapy; PABS-PT, the 19-item Pain Attitudes and Beliefs Scale for Physiotherapist. Values are presented as mean (95\% confidence interval of lower bound-upper bound), or numbers [\%]. *Fisher's exact test demonstrated a statistical significant difference in the ratio of "guideline-inconsistent" and "guideline-consistent" between the groups in activity (P = 0.007), work ( $\mathrm{P}$ $=0.046)$ and bed rest $(\mathrm{P}<0.001)$. ${ }^{\dagger}$ Independent sample t-test demonstrated a statistical significant difference $(\mathrm{P}<0.001)$ between the groups.

the updates in evidence-based physiotherapy, which may result in very low usage of the Physiotherapy Evidence Database in Japan [18]. We postulate that the lack of reading research papers in English may be due to, at least in part, the language barrier. Even then, reading research papers in Japanese language is also limited amongst Japanese therapists. Therefore, we speculate that Japanese physical therapists are not very driven to seek evidence-based physiotherapy from academic sources for clinical practice purpose. We propose that the Japanese institutions for physical therapy education should educate students so that they will be competent enough to find information on evidence-based physiotherapy from academic sources for use in their clinical decision making.

The potential contributors to adherence to LBP practice guidelines include the Cred.MDT and the highest education level attained. These findings are not surprising considering that the educational curriculum to obtain the Cred.MDT license is standardized throughout the world, which is a postgraduate education level. Therefore, we contend that the Cred.MDT therapist has similar knowledge about musculoskeletal disorders compared to those with postgraduate degree. Holders of higher academic qualifications are expected to have more knowledge about evidence-based clinical practice than holders of lower academic qualifications.

The Cred.MDT therapist group had a lower biomedical/behavioral ratio than the general physical therapist group. The upper limit of $95 \%$ CI was $<1$ in the Cred.MDT group while the lower limit of $95 \%$ CI was $>1$ in the general physical therapist group. These indicate that the Cred.MDT therapists have more biopsychosocial treatment orientation than biomedical treatment orientation while the general physical therapists have more biomedical treatment orientation than bio-psycho-social treatment orientation. These findings may be attributed to at least two reasons. First, MDT is a treatment-based approach where decision making for management strategies is based on patient's symptom responses to mechanical loading [10] rather than findings by therapist's observa- 
tions and palpation. Therefore, in MDT it is more important to classify patients into subgroups for suggesting a promising treatment strategy to them than identifying specific pathology producing pain (i.e. biomedical treatment orientation). Second, MDT emphasizes on patient education which empowers patients with the knowledge to self-manage their LBP condition, that is, compliance to home exercises and self-monitoring of posture and habits [10] rather than solely passive treatments in the clinic by therapists. Furthermore, self-treatment program of MDT is tailored to the life style of the patient. Therefore, psycho-social aspects are considered during MDT assessments and treatments to maximize patient's achievement of the self-management strategy.

This study indicated that the Cred.MDT therapists were more biopsychosocial treatment orientated than biomedical treatment orientated but it is uncertain whether learning MDT will change therapist's treatment approach from a biomedical to a biopsychosocial perspective. It would be interesting to investigate the change in therapist's treatment perspective in response to MDT education in a prospective study to determine the benefit of learning MDT for disseminating evidence-based clinical practice for LBP not only in Japan but also countries with limited evidence-based clinical practice in the management of LBP.

\section{Limitations}

One of the limitations in this study is our small sample size in particular for the general physical therapists group. We anticipated a $10 \%$ response from the general physical therapist group (i.e. 200 data samples) while 92 data samples were required to adequately reflect a target sample of 2000 general physical therapists (95\% confidence level and $10 \%$ margin of error). However, the actual response ratio was lower than our expectation. Furthermore, this study used voluntary response sampling, which is a limitation by ethical concerns. Thus, it is likely that the general physical therapists group was not sufficiently represented. However, it is possible that the low response in the general physical therapist group indicates the lack of opportunities or motivation to consider adherence to LBP practice guidelines or biopsychosocial perspectives for LBP management. In addition, there were more samples $(\mathrm{N}=90)$ than the minimum sample size to run the multiple regression analysis of this study, which was estimated by $\mathrm{G}^{*}$ Power 3 [19] ( $\mathrm{n}=70$; strong effect size $\mathrm{F}^{2}=0.35, \alpha=0.05,1-\beta=0.95,7$ predictors). Therefore, we believe that the results of this study would not have been different even if the sample size of the general physical therapists group was sufficient (>200).

\section{Acknowledgements}

The authors wish to acknowledge cooperators for processing cross-cultural adaptation of the scale for the adherent to low back pain practice guidelines [14] and the Pain Attitudes and Beliefs Scale for Physiotherapist (PABS-PT) [16] [17] (Mr. Hiroyuki Hasegawa [coordinator], Mr. Katsumi Goto and Ms. Ai Nagayasu [forward translation], Mr. Shousei A. Kawamoto and Mr. Tadahiro Okutani [backward translation], Mr. Takahiro Miki, Ms. Chise Katsuyama and Ms. Michi Wada [committee member], and Dr. Raymond W. J. G. Ostelo [original author of the PABS-PT]). The authors also would like to thank Mr. Masao Yamauchi for assisting data collection.

\section{References}

[1] Feuerstein, M., Hartzell, M., Rogers, H.L., et al. (2006) Evidence-Based Practice for Acute Low Back Pain in Primary Care: Patient Outcomes and Cost of Care. Pain, 124, 140-149. http://dx.doi.org/10.1016/j.pain.2006.04.007

[2] Fritz, J.M., Cleland, J.A. and Brennan, G.P. (2007) Does Adherence to the Guideline Recommendation for Active Treatments Improve the Quality of Care for Patients with Acute Low Back Pain Delivered by Physical Therapists? Medical Care, 45, 973-980. http://dx.doi.org/10.1097/MLR.0b013e318070c6cd

[3] Rutten, G.M., Degen, S., Hendriks, E.J., et al. (2010) Adherence to Clinical Practice Guidelines for Low Back Pain in Physical Therapy: Do Patients Benefit? Physical Therapy, 90, 1111-1122. http://dx.doi.org/10.2522/ptj.20090173

[4] Koes, B.W., van Tulder, M., Lin, C.W., et al. (2010) An Updated Overview of Clinical Guidelines for the Management of Non-Specific Low Back Pain in Primary Care. European Spine Journal, 19, 2075-2094. http://dx.doi.org/10.1007/s00586-010-1502-y

[5] Hendrick, P., Mani, R., Bishop, A., et al. (2013) Therapist Knowledge, Adherence and Use of Low Back Pain Guidelines to Inform Clinical Decisions-A National Survey of Manipulative and Sports Physiotherapists in New Zealand. Manual Therapy, 18, 136-142. http://dx.doi.org/10.1016/j.math.2012.09.002

[6] Learman, K.E., Ellis, A.R., Goode, A.P., et al. (2014) Physical Therapists’ Clinical Knowledge of Multidisciplinary 
Low Back Pain Treatment Guidelines. Physical Therapy, 94, 934-946. http://dx.doi.org/10.2522/ptj.20130567

[7] Battie, M.C., Cherkin, D.C., Dunn, R., et al. (1994) Managing Low Back Pain: Attitudes and Treatment Preferences of Physical Therapists. Physical Therapy, 74, 219-226.

[8] Foster, N.E., Thompson, K.A., Baxter, G.D., et al. (1999) Management of Nonspecific Low Back Pain by Physiotherapists in Britain and Ireland. A Descriptive Questionnaire of Current Clinical Practice. Spine, 24, 1332-1342. http://dx.doi.org/10.1097/00007632-199907010-00011

[9] Hurley, D.A., Dusoir, T.E., McDonough, S.M., et al. (2000) Biopsychosocial Screening Questionnaire for Patients with Low Back Pain: Preliminary Report of Utility in Physiotherapy Practice in Northern Ireland. Clinical Journal of Pain, 16, 214-228. http://dx.doi.org/10.1097/00002508-200009000-00007

[10] McKenzie, R. and May, S. (2003) The Lumbar Spine: Mechanical Diagnosis and Therapy. 2nd Edition, Spinal Publications New Zealand Ltd., Waikenae.

[11] Green, S.B. (1991) How Many Subjects Does It Take to Do a Regression Analysis? Multivariate Behavioral Research, 26, 499-510. http://dx.doi.org/10.1207/s15327906mbr2603_7

[12] Maxwell, S.E. (2000) Sample Size and Multiple Regression Analysis. Psychological Methods, 5, 434-458. http://dx.doi.org/10.1037/1082-989X.5.4.434

[13] Evans, D.W., Breen, A.C., Pincus, T., et al. (2010) The Effectiveness of a Posted Information Package on the Beliefs and Behavior of Musculoskeletal Practitioners: The UK Chiropractors, Osteopaths, and Musculoskeletal Physiotherapists Low Back Pain Management (Complement) Randomized Trial. Spine, 35, 858-866. http://dx.doi.org/10.1097/BRS.0b013e3181d4e04b

[14] Evans, D.W., Foster, N.E., Underwood, M., et al. (2005) Testing the Effectiveness of an Innovative Information Package on Practitioner Reported Behaviour and Beliefs: The UK Chiropractors, Osteopaths and Musculoskeletal Physiotherapists Low Back Pain Management (Complement) Trial. BMC Musculoskeletal Disorders, 6, 41. http://dx.doi.org/10.1186/1471-2474-6-41

[15] Beaton, D.E., Bombardier, C., Guillemin, F., et al. (2000) Guidelines for the Process of Cross-Cultural Adaptation of Self-Report Measures. Spine, 25, 3186-3191. http://dx.doi.org/10.1097/00007632-200012150-00014

[16] Ostelo, R.W.J.G., Stomp-van den Berg, S.G.M., Vlaeyen, J.W.S., et al. (2003) Health Care Provider's Attitudes and Beliefs towards Chronic Low Back Pain: The Development of a Questionnaire. Manual Therapy, 8, 214-222. http://dx.doi.org/10.1016/S1356-689X(03)00013-4

[17] Houben, R.M., Ostelo, R.W., Vlaeyen, J.W., et al. (2005) Health Care Providers' Orientations Towards Common Low Back Pain Predict Perceived Harmfulness of Physical Activities and Recommendations Regarding Return to Normal Activity. European Journal of Pain, 9, 173-183. http://dx.doi.org/10.1016/j.ejpain.2004.05.002

[18] Campos, T.F., Beckenkamp, P.R. and Moseley, A.M. (2013) Usage Evaluation of a Resource to Support EvidenceBased Physiotherapy: The Physiotherapy Evidence Database (PEDro). Physiotherapy, 99, 252-257. http://dx.doi.org/10.1016/j.physio.2012.12.001

[19] Faul, F., Erdfelder, E., Lang, A.G., et al. (2007) G*Power 3: A Flexible Statistical Power Analysis Program for the Social, Behavioral, and Biomedical Sciences. Behavior Research Methods, 39, 175-191. http://dx.doi.org/10.3758/BF03193146 


\section{Appendix 1: The Japanese Adherence to Low Back Pain Practice Guidelines.}

An English original questionnaire is available in [14] for Appendix 1.

以下のケースに対して、あなたはどのように対応しますか？以下の 3 つの質問全てに対して、最も 適切なものに○をつけてください。

28 歳、女性。腰痛既往歴無し。3 週間前に仕事で $10 \mathrm{~kg}$ の箱を持ち上げたときから腰痛あり。患者は病 院のカフェテリアの仕事をこなす事ができず、腰痛発症以来仕事を休んでいる。痛みで動けないと感 じていて、仕事への復帰も不安に思っている。仕事内容は様々ではあるが、身体的な負担になるもの はほとんどない。患者はフルタイムで勤務しており、家には頼れる人がいない。患者は、腰痛の痛み で我慢できなくまるまで、10 分ほど座位を保持出来き、10 0 メートルほど歩行することが出来る。 夜は眠る事ができるが、朝起きた際には腰部のこわばりを感じ、10分ほどそれが継続する。これま で、外傷や重度の疾患既往は無い。痛みは腰部に限定しており、放散痛は無い。身体的検査では、明 らかな前屈の制限と左腰部の圧痛がある。神経的な検査は正常で、SLR90。 を超えても痛みが増加しな い。その他の問診・身体的検査でも特記すべき点はなく、腰痛が始まってから医療従事者を訪れたこ とは無い。
A. 活動：痛みが改善するまで、私は患者に以下のことを勧める。
1. 全ての身体的活動を制限する
2. 軽度な活動以外を制限する
3. 中程度の活動まで制限する
4. 痛みを伴う活動のみ制限する
5. 全ての活動を制限しない
B. 仕事：痛みが改善するまで、私は患者に以下のことを勧める。
1. 仕事を休む
2. パートタイムで軽い仕事を行う
3. フルタイムで軽い仕事を行う
4. パートタイムで通常通りの仕事を行う
5. フルタイムで通常通りの仕事を行う
C. 寝て休む：私は患者に以下のことを薦める。
1. 痛みが完全に消失するまで誛て休む
2. 痛みがかなり改善するまで、㾛て休む
3. 痛みが重度の時のみ、寝て休む
4. 可能な限り寝て休むのを避ける
5. 寝て休むのを完全に避ける

※ガイドライン準拠は、質問 $\mathrm{A}$ では 4 以上、質問 B では 3 以上、質問 C では 4 以上とする。 


\section{Appendix 2: The Japanese Pain Attitudes and Beliefs Scale for Physiotherapist.}

An English original questionnaire is available in [16] and [17] for Appendix 2.

このアンケートの目的は、あなたが最も一般的なタイプの腰痛に対して、どのようにどの様にアプ ローチをしているかを知ることです。ここで言う腰痛とは、神経根症候群、馬尾症候群、骨折、感染 症、炎症型の症例、腫瘍、転移などが原因で起こったものではないものとします。このアンケートは あなたの腰痛に関する知識を問うものではなく、単純に、あなたが実際どのようにアプローチしてい るかを知るためのものです。他人の意見や一般的な考え方ではなく、あくまであなた個人の意見をお 聞かせ下さい。

全ての質問お答え下さい。最も適切なレベルにレを記入して下さい)

1. Biomedical subscale

1.1

2. Behavioral subscale

腰の痛みが増す場合、私はそれに合わせて速やかに治療の強度を調整する。

正常な機能に回復するための前提として、疼痛軽減は必要である。

疼痛の増加は、新たな組織の損傷か既在の損傷の広がりを意味する。

疼痛レベルは組織損傷の程度によって決定される。

精神的なストレスは組織の損傷が無くても腰痛の原因になりうる。

腰痛の原因は不明である。

エクササイズは重度の腰痛患者に良い影響をもたらす。

腰痛による機能障害は心理社会的要因によって引き起こされる。

腰痛を完全に取り去る効果的な治療法は無い。

たとえ痛みが残っていたとしても、治療は成功していると言える場合があ る。

疼痛が悪化したとしても、次回の治療強度が引き上げられる場合がある。

ストレスの対処法を学ぶことは腰痛の回復を促進させる。

治療中、腰に負荷をかけて痛みを引き起こす可能性のあるエクササイズは 避けるべきではない

(1)


Scientific Research Publishing (SCIRP) is one of the largest Open Access journal publishers. It is currently publishing more than 200 open access, online, peer-reviewed journals covering a wide range of academic disciplines. SCIRP serves the worldwide academic communities and contributes to the progress and application of science with its publication.

Other selected journals from SCIRP are listed as below. Submit your manuscript to us via either submit@scirp.org or Online Submission Portal.
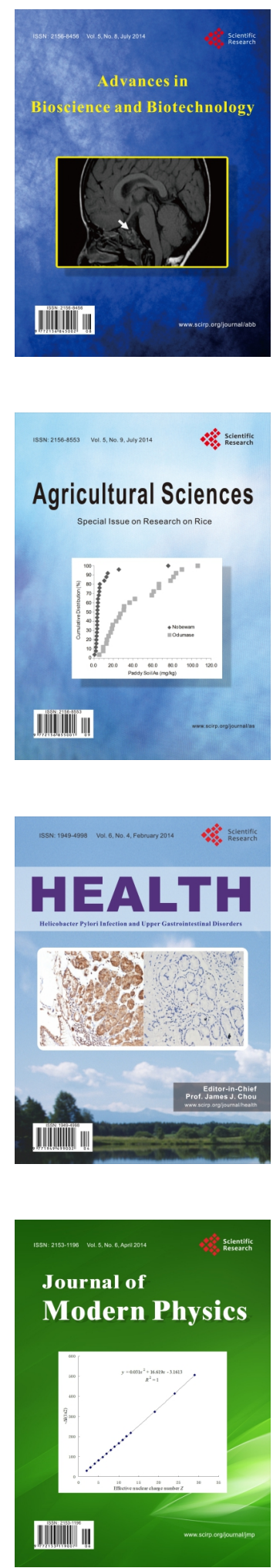
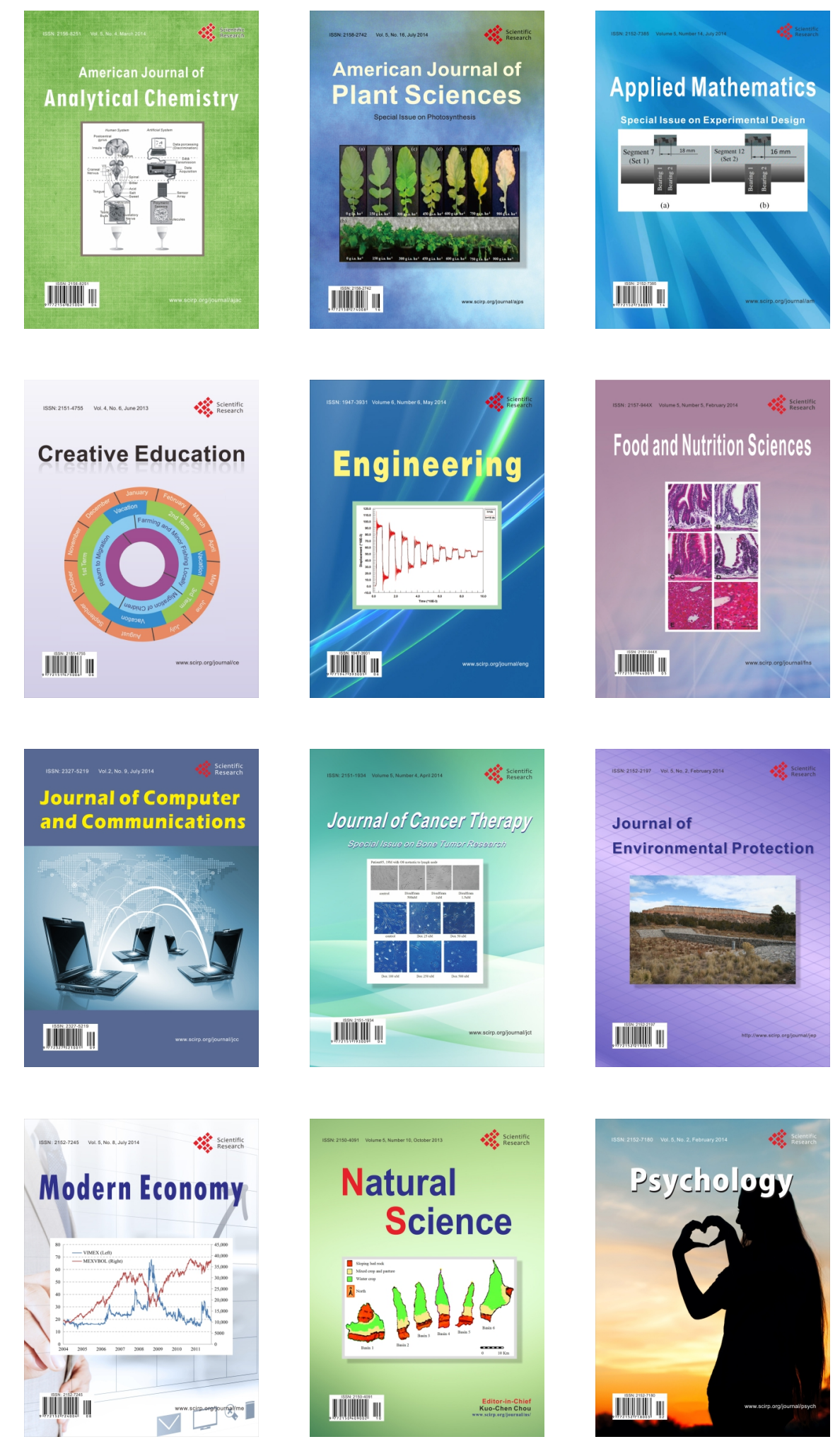